\title{
Note by the editors
}

\section{Managing Editor: Ingo Plag1}

Published online: 11 February 2016

(c) Springer Science+Business Media Dordrecht 2016

Starting with volume 26 (2016) Morphology welcomes a new editor, Ana Luís (University of Coimbra, Portugal). Ana replaces Geert Booij, who has resigned as editor after 28 years (!) in this capacity, first as editor of Yearbook of Morphology, and, since 2006, as editor of Morphology, after the Yearbook became a regular journal. The field of morphology has profited immensely from his work, and many of us have learned a great deal through his meticulous editorship and careful guidance. Thank you so much, Geert!

I. Plag

Ingo.Plag@uni-duesseldorf.de

1 Duesseldorf, Germany 